\title{
HAVE EURO AREA AND EU ECONOMIC GOVERNANCE WORKED?
}

\section{JUST THE FACTS}

by Demosthenes loannou and Livio Stracca 


\author{
HAVE EURO AREA \\ AND EU ECONOMIC \\ GOVERNANCE WORKED?
}

JUST THE FACTS ${ }^{\prime}$

by Demosthenes loannou and Livio Stracca ${ }^{2}$
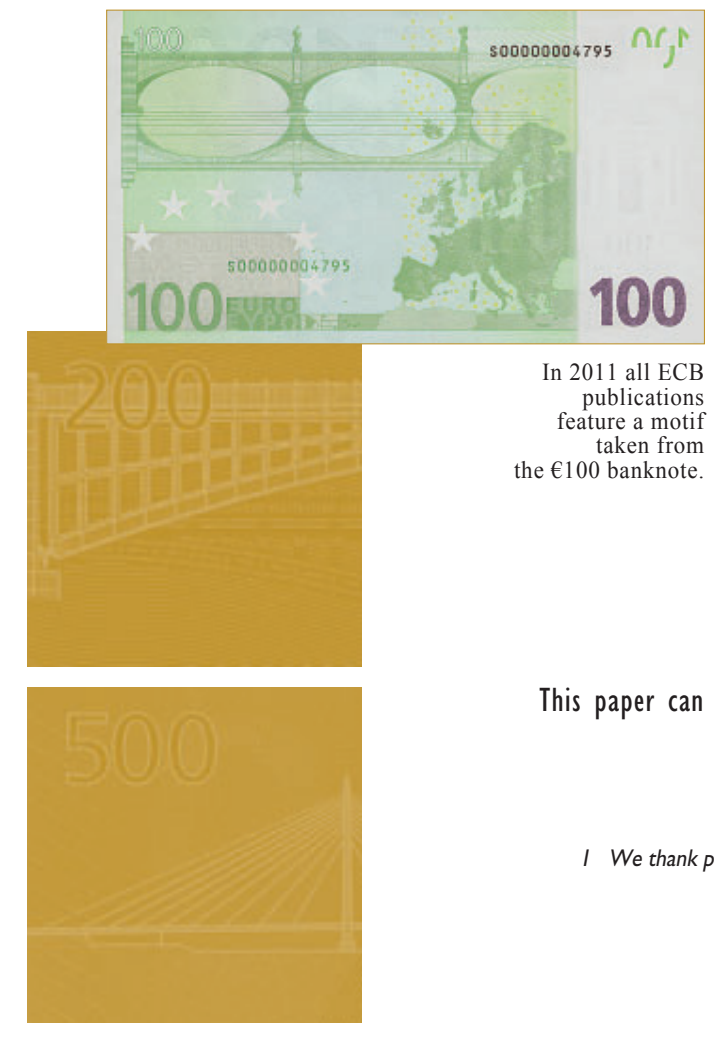

NOTE: This Working Paper should not be reported as representing the views of the European Central Bank (ECB). The views expressed are those of the authors and do not necessarily reflect those of the ECB. 
(C) European Central Bank, 2011

\section{Address}

Kaiserstrasse 29

60311 Frankfurt am Main, Germany

Postal address

Postfach 160319

60066 Frankfurt am Main, Germany

Telephone

+496913440

Internet

http://www.ecb.europa.eu

Fax

+496913446000

All rights reserved.

Any reproduction, publication and reprint in the form of a different publication, whether printed or produced electronically, in whole or in part, is permitted only with the explicit written authorisation of the ECB or the authors.

Information on all of the papers published in the ECB Working Paper Series can be found on the ECB's website, http://www. ecb.europa.eu/pub/scientific/wps/date/ html/index.en.html

ISSN 1725-2806 (online) 


\section{CONTENTS}

Abstract

Non-technical summary

1 Introduction

2 Literature review: the stability and growth pact

3 Data

4 A first look at the evidence

5 The stability and growth pact and fiscal behaviour

5.1 Empirical model

5.2 Results

6 The Lisbon strategy and economic performance

6.1 Empirical model

6.2 Results

7 Conclusions

References

Tables 


\begin{abstract}
We test whether two key elements of the EU and euro area economic governance framework, the Stability and Growth Pact and the Lisbon Strategy, have had any impact on macroeconomic outcomes. We test this proposition using a difference-in-difference approach on a panel of over 30 countries, some of which are non-EU (control group). Hence, the impact of the EU economic governance pillars is evaluated based on both the performance before and after their application as well as against the control group. We find strong and robust evidence that neither the Stability and Growth Pact nor the Lisbon Strategy have had a significant beneficial impact on fiscal and economic performance outcomes. We conclude that a profound reform of these pillars is needed to make them work in the next decade.
\end{abstract}

Keywords: Stability and Growth Pact, Lisbon Strategy, euro area, European Union, governance, institutions.

JEL: 


\section{Non-technical summary}

This paper presents an ex post analysis of whether two key elements of the EU and euro area economic governance framework, the Stability and Growth Pact (SGP) and the Lisbon Strategy, have achieved their goals. Using a difference-in-difference approach in a panel setting, we look at a wide range of annual data coming from 36 countries, over a sample period from 1980 to 2010. We consider a large set of possible control variables, as well as variables which could interact with the success (or lack thereof) of the two EU governance pillars. Their performance EU is assessed both against the countries' own past performance as well as a control group of non-euro area or non-EU countries, controlling for different national economy characteristics.

Overall, our results indicate that so far economic governance in the EU and the euro area has had limited or no success. In particular, we find that

1) The Stability and Growth Pact has had no overall effect on the behaviour of the primary balance. While it has increased the counter-cyclicality of fiscal policy it has also increased its sensitivity to the political business cycle;

2) The Lisbon Strategy has had at best no impact on the behaviour of real per capita GDP growth, employment growth and labour productivity growth.

For the SGP, an optimistic reading of our results is that finding no effect of the SGP on fiscal outcomes is an indicator of success since it implies that this institutional framework has prevented the establishment of Economic and Monetary Union to adversely affect fiscal behaviour, a risk that was emphasised widely in the run-up to the euro. However, we consider that an appropriate set of fiscal rules in a monetary union should go beyond the no-change outcome and impose greater fiscal discipline than otherwise, on account of the possible negative spillovers that fiscal profligacy in individual countries may have on other EMU participants whether via the single monetary policy or otherwise, as well as the possible reduction in market discipline for individual Member States brought about by a stable and solid single currency. Our results indicate that the SGP has not delivered according to this stricter benchmark.

The main policy implication stemming from our analysis is that substantial progress, or a "quantum leap", must be made in EU and euro area economic governance to ensure and enhance the gains of Economic and Monetary Union for the benefit of European citizens. 


\section{Introduction}

In the aftermath of the global financial crisis euro area Member States have experienced unprecedented challenges to their public finances in particular, and their economic policies more generally. These challenges have exposed the weaknesses of the two pillars of EU and euro area economic governance, namely the fiscal framework of the Maastricht Treaty and the Stability and Growth Pact (SGP) on the one hand, and the Lisbon Strategy (LS) on the other. Looking forward, it is essential to strengthen both pillars of EU economic governance. Before we look forward, however, we must set the record straight on the performance of these economic governance pillars looking backward, in their first decade. This paper tries to answer this question: have the SGP and the LS worked against the objectives that they were created for?

One main contribution of this paper is to extend beyond the EU and use non-EU OECD countries as a control group in an econometric investigation of the effectiveness of the SGP, applying a difference-in-difference approach where the outcomes are compared both in terms of their own past, for the group of countries which have been subject to the "treatment" (the EU economic governance pillars), as well as the performance of the countries in the control group, also taking into account the influence of a set of control variables. This approach goes beyond most contributions so far on the SGP which typically focus on EMU or EU countries alone (e.g. Gali and Perotti 2003, Annett 2006, Golinelli and Momigliano 2009, Bernoth et al. 2009). Moreover, existing studies usually consider significantly shorter samples (among those that are most related to our paper, Annett ends in 2004, and Gali and Perotti in 2002). Instead, we use annual data spanning from 1980 and up to 2009, covering 36 countries. Finally, we test not only for the effect of the SGP on average fiscal behaviour, but also extend our analysis to other possible dimensions of its influence, such as the degree of pro-cyclicality of fiscal policy, its being subject to the political cycle, and its responsiveness to market discipline. ${ }^{1}$

We also apply the same difference-in-difference approach vis-à-vis the non-EU OECD control group for the LS. In the case of the LS, our assessment comes at the time of conclusion of the original reform agenda and when the European Union is now ironing out the details of its successor strategy, Europe 2020. In this analysis, we also include a number of control variables that have come up in the literature on the political economy of structural reform. Unlike previous studies, we do not focus on reform efforts but rather on outcomes in terms of long term economic performance measures. To our knowledge, this type of exercise has not been performed before, at least in a systematic manner.

Our paper is related to several different strands of the fiscal policy literature, in particular to three of them. One is the political economy of fiscal policy. For example, it has been emphasised that fiscal profligacy may depend on the size and

\footnotetext{
${ }^{1}$ However, we don't consider the complementarities between fiscal policy and structural reforms (as, for example, in Buti et al. 2009).
} 
form of government (Buti and Pench 2004, Roubini and Sachs 1989), the design of electoral systems (Alesina and Tabellini 1990 and Persson and Svensson, 1989), the impact of partisan politics on fiscal policy (Lambertini 2000), the fragmentation of the budgetary process (Hallerberg 2004) and the politics of budget maximisation and fiscal illusion (Drazen 2004). Numerous reasons for the 'deficit and debt biases' have also been identified (for an overview see Schucknecht 2004; Drazen 2000 and Alesina and Perotti 1996) which range from the effects of the electoral cycle to excessively optimistic forecasts (Jonung and Larch 2006) and budget capture by pressure groups (Alesina and Drazen 1991). We include several political economy variables in our analysis.

A second strand of literature looks at fiscal rules and fiscal councils. Fiscal rules, defined as "a permanent constraint on fiscal policy, expressed in terms of a summary indicator of fiscal performance" (Kopits and Symansky 1998), are needed to deal with the problem of time inconsistency. The basic principle is "tying oneself to the mast" (Schelkle 2006), in order to avoid overspending over the business cycle. In this paper, we look at the SGP as a supra-national rule and do not focus, also for lack of data for our larger sample of countries, on national fiscal institutions such as in Debrun and Kumar (2007) and the possible interplay with the supra-national rule.

Third, there is a significant literature on the SGP as such. We report on this literature, and its relation with our work, in a separate section (Section 2).

Our main result is that the SGP and the LS have not significantly improved the performance of EU Member States in terms of fiscal policy and long term economic performance. Our result for the SGP (no significant impact of the SGP on the average behaviour of the primary balance) lends itself to an optimistic interpretation, since the establishment of a monetary union could have, per se (i.e. without the Stability and Growth Pact), led to a weakening of fiscal discipline and to larger deficits in absolute terms. Therefore, one possible reading of our finding is that the SGP was at least able to prevent this from happening, although our analysis is not based on a structural model and we can therefore run no counter-factual. However, we find this possible interpretation not very plausible and too complacent since another key objective of the SGP is to prevent fiscal irresponsibility in EU Member States from spilling over to the single monetary policy. This would call for more stringent limits on fiscal policy in a monetary union than otherwise, and on this account our results indicate that the SGP has not delivered. Overall, our results strengthen the case for a 'quantum leap' in the reform of the EU and euro area economic governance.

The paper is organised as follows. Section 2 reviews some literature on the SGP. Section 3 describes the data, while Section 4 gives a preliminary look at the evidence. Section 5 looks at the role of the SGP and the Maastricht Treaty to constrain and influence fiscal behaviour. Section 6 runs a similar analysis for the LS. Section 7 concludes and presents some policy implications. 


\section{Literature review: the Stability and Growth Pact}

There is already a copious literature on the SGP, to which for reasons of space we cannot do full justice. Here we briefly review a few of the issues that are most relevant for our analysis.

Buti, Eijffinger and Franco note (2003) that the Maastricht convergence criteria and, later, the SGP's 3\% deficit limit appeared acceptable to enforce fiscal discipline at a time when public finances in a number of EU countries appeared to be on an unsustainable path. In 1992, the EU's average debt ratio was almost $60 \%$ of GDP; by 1997 , it had climbed to almost $75 \%$. While this ratio fell to $63 \%$ in 2003 , von Hagen (2003) argues that this result cannot be directly attributed to the SGP and is subject to two qualifications. First, the increase in the average debt ratio from 1992-1997 was driven mainly by debt expansion in only five countries. Second, the decrease in the average debt ratio from 1997 to 2001 again saw small states outperform large states, achieving a reduction in their debt ratios of almost 20 percentage points (as against the average 5.3\% reduction in large states' debt ratios). Annett (2006) uses these findings to refine the argument that the SGP is inherently more suited to small countries, suggesting that the SGP "could be suited to a subgroup of countries that (i) are small and more likely to accept an external constraint; (ii) have the potential for macroeconomic volatility and so appreciate an external anchor; and (iii) rely on the commitment form of fiscal governance." Buiter (2005), writing on the same period, states more bluntly that as regards sustainability "the SGP has made a contribution... only where its prescriptions were incentive-compatible for the target country, that is, aligned with that country's domestic policy objectives."

As noted by von Hagen (2003), since most European countries had sizeable fiscal expansions during the 1970s and 1980s, a period of consolidation could be expected in the 1990s irrespective of the Maastricht criteria or the SGP's strictures. Thus, we can interpret what Fatás and Mihov (2003) described as countries' "consolidation fatigue" as an example of diminished incentive-compatibility. The ECB (2005) (see also Morris et al. 2006) noted that, from 1999, fiscal consolidation stalled or went into reverse in most euro-area countries. Economic downturn in 2001 led to deterioration in public finances, putting an increasing number of Member States at risk of, or firmly in, excessive deficit positions. Troubles in France and Germany led to the "suspension" of the SGP and its eventual reform in 2005, a development viewed with alarm by both the European Commission and the ECB.

More generally, Filipek and Schreiber (2010) state that until the onset of the global financial crisis, the SGP appeared to be successful: countries were meeting their Medium-Term Objectives (MTOs) and most had balanced budgets or even surpluses. However, it would seem wrong to attribute this to the 2005 reform which in fact weakened the Pact. Indeed, Buiter (2005) and Filipek and Schreiber agree that the SGP did not provide the incentives for necessary restraint during upswings to create room for expansionary measures during downturns. Furthermore, von Hagen (2003) 
noted that the narrow focus of the SGP on annual deficits may keep governments from adopting reform policies that might result in larger deficits initially before the desired growth and employment effects kick in.

The implementation of the SGP has obviously been followed and evaluated also by international institutions. The IMF (2010) emphasised how the crisis had exposed three long-standing weaknesses in the euro area's fiscal framework. First, the SGP had failed to encourage the buildup of sufficient buffers in good times and lower debt to prudent levels, limiting room for manoeuvre in bad times. Second, fiscal surveillance's narrow focus on procedural aspects and formal deficit limits, twinned with Council's reluctance to use binding legal instruments to mandate policy corrections in EDP enforcement, aggravated structural flaws. Third, the euro area fiscal framework lacked centralized crisis management and resolution capacities. The IMF (2010) thus advocated a strengthening of economic governance in EMU with a focus on enforcing budgetary discipline.

Finally, other research has considered more closely the connection between the SGP and national fiscal institutions and rules. Although the econometric analysis in this paper does not delve into national fiscal frameworks (as does for example Debrun and Kumar 2007), it is worth considering this aspect of the SGP in terms of relevance for our conclusions.

From a 'fiscal institutionalist' perspective, the SGP should be more successfully combined with "commitment" member states because it strengthens their rules-based frameworks; while the legitimacy of delegation states' ministers of finance is undermined by the SGP because they no longer have room for manoeuvre (Hallerberg 2004). However, country specific empirical evidence does not always fit this model (Hodson 2009). Moreover, factors such as the role of veto players in the budgetary process (e.g. German Bundesrat), or the degree of public spending decentralisation (Afonso and Hautpmeier 2009) also seem to affect fiscal outcomes.

In terms of the existing empirical research on the effects of the Stability and Growth Pact, Table 1 presents an overview of existing studies and key results. The general message arising from this literature (see e.g. Gali and Perotti 2003) is that the SGP does not seem to have had a major impact on fiscal behaviour in the euro area. One important difference with our approach, as noted, is that these studies are not based on difference-in-difference estimates and cover significantly smaller sample periods, typically up to the early to mid-2000s.

\section{Data}

The empirical analysis in the paper is based on annual data from 36, mostly advanced, countries, a list of which is contained in Table 2. The sample includes 25 EU countries, 15 of which are in the euro area now, and 11 non-EU countries. Since most variables are not available for all countries, in the regression analyses the country sample numbers between 30 and 34. The sample period is 1980 to 2009 . 
A number of macroeconomic variables have been obtained from "off the shelf" sources: the government budget balance and debt as a share of GDP, income per capita, employment, the labour share of income and labour productivity from the European Commission AMECO database; the output gap, the primary and cyclically adjusted primary balance, the government share of income (total government disbursements as a share of GDP) and trade openness from the OECD Economic Outlook database; population and the PPP share of world GDP from the IMF World Economic Outlook database; Research and Development expenditure, as a share of GDP, from the OECD STAN database; the Rule of Law indicator from the World Bank Governance Indicators database (available from 1996 onwards and updated to 2008; see Kaufmann et al. 2008); and a number of variables capturing the political business cycle and political institutions from the 2010 update of the Database of Political Institutions (see Beck et al. 2001). Finally, we also use OECD data on Employment Protection Legislation and Product Market Regulation, the latter interpolated to an annual frequency.

We also define dummy variables to capture the EU economic governance processes that we are interested in. As far as the Stability and Growth Pact is concerned, our baseline measure is a dummy variable $S G P$ which takes values 1 if a country is in the euro area and 0 otherwise. The reason for this choice is that the Stability and Growth Pact is an essential feature of the monetary union and that a supra-national fiscal rule is an important underpinning of the monetary union. It may also be argued that the fiscal limits set in the Maastricht Treaty and reinforced in the Stability and Growth Pact influenced country behaviour even before joining the euro, in the convergence process during the run-up to the single currency. We therefore also consider a variant of the dummy, $S G P \_P R E$, which takes value 1 also in the two years preceding the adoption of the euro. Moreover, we also compute a MAASTRICHT dummy taking value 1 from 1993 onwards for all EU countries (or from the moment they join the EU). Finally, we also consider the possibility that the nature of the Pact has changed after 2003, a year which, according to most observers, marked a significant weakening of the effective discipline that the Pact enforces. We therefore also defined SGP_PRE03 as a dummy variable defined as the baseline SGP but only until 2003, and zero afterwards.

As far as the LS is concerned, the definition is more straightforward here, since it applies to all EU countries after 2000. We compute a dummy variable $L I S B O N$ taking values 1 for all EU countries either from 2001 or from the year when they join the EU. We also consider the possibility that the LS is a cumulative process the effects of which multiply as time elapses following its first implementation. The variable $L I S B O N_{-} Y E A R S$ therefore computes, for each year, the number of years in which a certain country has been subject to the LS (this number is obviously zero for non-EU countries).

Table 3 reports the summary statistics for all variables used in this paper.

(Insert Tables 2-3 here) 


\section{A first look at the evidence}

We first look at basic summary statistics for the key variables that are relevant depending on whether countries are, or are not, subject to the SGP and to the LS. The data are reported in Table 4. Of course, this only represents preliminary, unconditional evidence as it treats all countries in the same way, irrespective of possible determinants, the only difference being whether they are subject to the modalities of EU and euro area economic governance or not.

For fiscal variables, the data look clearly better for countries which (and when they) have been subject to the SGP. The average primary balance is $+0.3 \%$ within the SGP, and $-1.2 \%$ without it. Countries under the SGP have also experienced less variation, with a standard deviation of $3.3 \%$ (including both cross section and time series variation) against $4.4 \%$. Results are similar for the other definitions of the EU fiscal rules that we propose (MAASTRICHT, SGP_PRE, SGP_PRE03). Prima facie, therefore, one is tempted to conclude that the SGP has been a success in increasing the average level as well as in reducing the standard deviation of the primary balance. We will see, however, that this conclusion does not survive in the conditional analysis, where we include other possible determinants of the primary balance.

\section{(insert Table 4 here)}

Concerning the LS, the unconditional results are less promising. Average per capita income growth, perhaps the best single yardstick of the LS (more discussion on this later), has been $1.2 \%$ on average in the countries subject to the Lisbon Strategy, against $2.4 \%$ in other countries (including EU countries before 2000), and with a higher standard deviation.

\section{The Stability and Growth Pact and fiscal behav- iour}

\subsection{Empirical model}

We address the problem of evaluating the impact of the EU fiscal institutions (the SGP and Maastricht) in three sequential steps. First, we estimate a model of ex post fiscal behaviour over the full set of countries (both EU and non-EU), similar to, for example, Gali and Perotti (2003). The model is specified on the primary balance, that is, not the cyclically adjusted budget balance. The choice of this left hand side variable - rather than the more common cyclically adjusted one - is motivated by our desire to study how the fiscal institutions have shaped not only the average behaviour of governments but also their responsiveness to the business cycle, that is, the degree of pro-cyclicality of fiscal policy. 
This general model may be specified as a difference-in-difference panel data model,

$$
\text { Primary }_{i t}=\alpha \text { Primary }_{i, t-1}+\beta x_{i t}+\gamma_{i}+\delta_{t}+\varepsilon_{i t}
$$

where $i$ is the country, $t$ the year, Primary the primary balance, and the $x$ vector including a number of possible determinants of fiscal behaviour, both of an economic and a political/institutional nature. Note that in the $x$ vector we include the output gap which may give rise to a reverse causality problem; for this reason, the equation is estimated by instrumental variables using GMM. ${ }^{2}$ The model also includes country fixed effects and time dummies, and a correction for the small sample is applied everywhere.

In a second step, we want to see whether the SGP - here a short-cut for the set of possible EU fiscal rules that we consider - matters for the average behaviour of fiscal policies,

$$
\operatorname{Primary}_{i t}=\alpha \text { Primary }_{i, t-1}+\beta x_{i t}+\gamma_{i}+\delta_{t}+\lambda S G P_{i t}+\varepsilon_{i t}
$$

If the SGP dummy is significant, then the behaviour of countries subject to the supra-national rule is systematically different from that of similar countries that are not subject to the rule. In proceeding in this way we are consistent with the literature on the econometrics of program evaluation (see Imbens and Wooldridge 2009 for a survey).

The third and final step is to analyse whether the rule affects the elasticity of fiscal policies to changes in the economic and institutional environment. We therefore extend the model in (2) to include interaction terms with a subset $y$ of the $x$ vector:

$$
\operatorname{Primary}_{i t}=\alpha \text { Primary }_{i, t-1}+\beta x_{i t}+\gamma_{i}+\delta_{t}+\lambda S G P_{i t}+\mu y_{i t} * S G P_{i t}+\varepsilon_{i t}
$$

One key question is whether the SGP has made fiscal policies more or less procyclical. That question may be addressed by looking at the interaction term between the output gap and the SGP dummies, and is tackled as such later. Note that since $S G P_{i t}$ is a binary dummy taking values zero and 1 , the $\mu$ parameter can be interpreted as a marginal effect, that is, the marginal benefit of moving from a situation of no treatment $(S G P=0)$ to treatment $(S G P=1)$.

We should emphasise at this point that this analysis is ex post and does not, therefore, aim at estimating an ex ante fiscal policy rule in the same way as papers based on real time variables do (Beetsma et al. 2009; Golinelli and Momigliano 2009; Cimadomo 2009). Another concern that one may have on our approach is that the decision to join the euro and the EU or euro area fiscal institutions may be an endogenous one, which may give rise to reverse causality since the treatment is not

\footnotetext{
${ }^{2}$ One lag of the output gap is used as the instrument, which implies that the equation is exactly identified. There is no sign of weak instruments in this estimation. Note that in our case $T$ is approximately the same size as $N$, which suggests that the Nickell (1981) bias should be, if anything, small; see Judson and Owen (1999).
} 
given exogenously. There is indeed some evidence that countries joining the euro have had (in the year preceding entry) a higher public debt to GDP ratio than countries which have not adopted the euro. For example, the 11 countries which formed the euro area in 1999 had a combined debt to GDP ratio of $64.3 \%$, against $47.1 \%$ in the remaining countries (a situation which has reversed since then). Since having a higher debt may increase incentives towards fiscal consolidation especially beyond a certain level, our empirical approach may entail a small bias towards finding a positive effect for the fiscal rule variables. Note that this is only relevant for the conditions prevailing at the time of euro area (or EU) entry. The effect of higher or lower debt over the whole sample is already captured in our model by the country fixed effect (see Imbens and Wooldridge 2009, in particular page 70); we also include the lagged debt to GDP ratio in the $x_{i t}$ vector. ${ }^{3}$

\section{$5.2 \quad$ Results}

The results of the estimation of equation (1) are reported in Table 5. A high debt to GDP ratio in the previous year, higher trade openness and economic size all contribute to a better primary balance. By contrast, income per capita and the size of government are statistically insignificant. The result for economic size is interesting in view of the consideration that larger countries typically have larger fiscal multipliers (Buti and Pench 2004); this may imply that they have less need for expansionary fiscal policies. The output gap is positive and significant, at around 0.3 , indicating that average fiscal behaviour is counter-cyclical. ${ }^{4}$ We also test (second column) whether there is any indication of asymmetry between a positive and a negative output gap, and we find that the source of counter-cyclicality only comes from times in which the output gap is positive (good times). Due to the relatively large size of the standard errors, however, we are not able to conclude that the difference in the coefficients associated to positive and negative output gaps is statistically significant. ${ }^{5}$

In the third column, we add political variables taken from the Database of Political Institutions. We consider several variables capturing (i) the political cycle, (ii) the strength and cohesion of the government, (iii) political stability and (iv) a measure of fiscal centralization. We find that years in which legislative elections take place are strongly associated to a worse primary budget balance, by about $0.5 \%$ and statistically highly significant. This confirms the existing widespread evidence in the literature of a political business cycle in our sample of countries. We also find that the vote share of the government parties is associated to better budgetary outcomes, indicating that stronger governments are better able to keep the fiscal house in order. Finally, a

\footnotetext{
${ }^{3}$ To deal with the problem of EMU entry endogeneity, Alesina, Ardagna and Galasso (2008) use instead an instrumental variable approach, where the instruments are the estimated probabilities of joining a monetary union.

${ }^{4}$ This result is very robust to changes in the instruments list.

${ }^{5}$ The Wald test is not reported for brevity.
} 
variable identifying countries where legislators are elected using a winner-take-all rule (plurality) is also significant and positive, probably again indicating that countries with stronger governments are better able to manage public finances. ${ }^{6}$

In the next two columns, we analyse a shorter sample (1992-2009) and take out 2008 and 2009 from the baseline sample, i.e. the special conditions of the global financial crisis. Overall, results are similar to the baseline exercise.

The sixth column reports results for the cyclically adjusted budget balance. Not surprisingly, the output gap is now insignificant. Moreover, two of the three political variables now also become insignificant.

\section{(Insert Table 5 here)}

Turning to equation (2), Table 6 reports results for the different versions of the Stability and Growth Pact dummy. As can be seen, they are invariably insignificant, implying that the EU (euro area) fiscal rule is irrelevant to explain the average behaviour of the primary balance once the control variables are included. We discuss the possible interpretations of this result later. At this stage, we only recall that our procedure has, if anything, a small bias towards finding a significant effect, which implies that the "no effect" result is robust and possibly even conservative. We also test whether the SGP matters at least for countries which have a deficit to GDP ratio above $2 \%$. One would expect that at least countries in this position should be pushed harder towards fiscal consolidation under the SGP than otherwise. What we find is, instead, the opposite: the SGP appears to have reduced countries' incentives to pursue a correction in the primary balance after being in an excessive deficit procedure, probably on account of the "bonus" represented by the low level of interest rates under EMU.

(Insert Table 6 here)

Furthermore, we report results for the estimation of equation (3) in Table $\%$. Starting from our baseline measure of the SGP (first column), it can be seen that the fiscal rule appears to have made countries more counter-cyclical but also more subject to the political cycle than otherwise. ${ }^{7}$ This result is, however, not very robust to the definition of the SGP dummy and it could therefore be an outcome that is associated more to the euro area per se rather than to its fiscal framework, though it is very difficult to distinguish the two interpretations based on our data. Our result stands in contrast with Gali and Perotti (2003) who found that pro-cyclicality was more muted after the adoption of the Maastricht Treaty. Their results may have been affected, however, by the Maastricht criteria themselves and the run-up to the introduction

\footnotetext{
${ }^{6}$ We do not include the Rule of Law indicator because it would reduce the sample size too much and because it is probably not very relevant to explain fiscal behaviour in rich countries.

${ }^{7}$ Buti et al. (2004) find similar early evidence for the impact of the political business cycle under EMU.
} 
of the euro in the 1990s. From the interaction term between economic size and the SGP, we also find no evidence that smaller economies have systematically benefited more from the SGP contrary to what is suggested, for example, by von Hagen (2003) and Annett (2006).

Finally, we want to establish whether the Stability and Growth Pact has affected the role of market discipline which, as noted by many observers, seems to have operated in quite an inefficient way in EMU, with government bond spreads being first very small and not reactive to fiscal conditions, and then (from 2008 onwards) very large and exceptionally responsive. What we want to test here is not whether government bond spreads react to fiscal imbalances, as commonly acknowledged in the literature, but rather the other way round, namely, if for given spreads the primary balance reacts to market signals. In the last column of Table 7 , therefore, we include an interaction term between the SGP and the previous year's long-term government bond spread versus the United States Treasury bond yield, taken to represent a global safe-asset benchmark. There is surprisingly little literature on the disciplining role of the bond market on government behaviour. Lane (1993) sets out some general conditions for market discipline to be effective. De Haan and Sturm (2000) study government bond spreads in Europe and come to the conclusion that market discipline is not very effective. ${ }^{8}$ Our results indicate that market discipline - as measured by the influence of government bond spreads in the previous year on the current year's primary balance - does not seem to matter much in the determination of primary balances more generally, and this has been so also under the SGP. We also add squared terms of these variables to capture possible non-linearities but these are again statistically insignificant. Therefore, we take this as an indication that if the SGP has had any effect, it is not through its influence on the working of market discipline on government behaviour (although it may still have influenced market discipline meant as the responsiveness of yield spreads to fiscal imbalances).

(Insert Table 7 here)

\section{The Lisbon Strategy and economic performance}

Moving beyond the EU/euro area fiscal rules, we consider the possible impact of the Lisbon Strategy (LS) on structural economic performance. We look at outcomes and do not consider reform efforts. This distinguishes our paper from other papers such as Duval and Elmeskov (2006) and Alesina, Ardagna and Galasso (2008), which have tried inter alia to establish a link between the intensity of structural reforms and the introduction of the euro. An important characteristic of the LS was precisely that it did not focus on a particular set of structural reforms to be implemented, leaving individual EU countries much freedom under the central coordinating procedures of the

\footnotetext{
${ }^{8}$ Bulut (2009) also finds little evidence of market discipline for sovereign borrowers of developing countries.
} 
Broad Economic Policy Guidelines and the Employment Guidelines (the "Integrated Guidelines" post-2005) to pursue their own ways. The LS did, however, contain a number of quantitative objectives in terms of outcomes (Ioannou et al. 2008). From a methodological perspective, in trying to ascertain the marginal contribution of the LS, we need to control for a series of determinants that have been identified in the literature as potential determinants of reform effort and economic performance. For this, we have looked at the literature on the political economy of structural reform.

This literature has emphasised, in particular, the degree of openness of the economy (which makes it easier to convince stakeholders given the higher degree of external competition (IMF 2006)); the size of the economy, with smaller countries being more open (Alesina and Wacziarg 1998) and more culturally homogenous, thereby allowing greater effectiveness of decision making; the degree of centralisation/devolution of decision making processes, with the former implying less resistance (Tompson 2009); the form of electoral rules, that is, majoritarian versus proportional, with the latter implying less power sharing and more consensus (Boeri et al. 2006), but possibly also implying more sustainable solutions which reflect the interests of broad majorities (IMF 2004); the nature of the political system, with parliamentary based systems possibly being more flexible than presidential.

As for the possible reasons behind the shortcomings of the LS in particular, the latest literature highlights several of the factors already identified by the Kok Report (2004) and the European Commission (2005) already back in the mid-2000s when the Lisbon Strategy underwent a reform in parallel to the SGP reform. In particular, as also explained by Ioannou et al. (2008), the reform of the LS did not achieve a sharper focus of the aims of the Strategy nor of the enhancement of the governance tools used to implement it (e.g. benchmarking against quantitative objectives).

Searching for a deeper cause, Ruta (2009), Collignon (2009) and Schout and Jordan (2008) all tend to attribute the failure of the Lisbon Strategy to national political constraints. Ruta (2009) in particular emphasises that, because national governments in the EU have retained practically sole competence in economic policy, spillover effects of reform are not fully internalized, which allows vested interests to lobby successfully in national capitals. Particularly relevant in this regard have been the financial, and more broadly, services sector which have been targets for liberalisation under the Lisbon Strategy. Collignon (2009) finds the EU's disappointing performance to be the result of a collective action problem which emerges "when autonomous governments seek to maximise collective utilities in isolated constituencies" (p. 76). Schout and Jordan (2008) argue that much of the Lisbon Strategy relied on modes of "networked governance" whereby central bodies depended upon the cooperation and joint resource mobilization of policy actors outside their hierarchical control. The authors question whether national and sub-national administrations have upgraded their co-ordinating capacities to make network-based modes function effectively. Koczor (2009) identifies objective and subjective factors influencing states' implementation of the Lisbon Strategy. Under the former heading, he includes the 
general level of development of a country and society's adaptability to the globalisation process. Under subjective factors, Koczor notes the importance of efficiency of governmental action, political will and the consensus for reform, the extent to which non-governmental entities (employer and employee organisations) work with the government to draft and implement the strategy, as well as the social acceptance of reform.

Wyplosz (2010), in line with the call by Ioannou et al. (2008) for a more explicit benchmarking, argues that the shift from pointed criticism to diplomatic peer pressure from the Commission undermined the process. Further, he notes that "political leaders are not raised to encourage critical comments from each other. More importantly, perhaps, while even polished exercises of apparent mutual admiration could still exercise some pressure, political leaders never forget that they are accountable to domestic voters."

Finally, Padoan (2009) sees an incomplete policy mix and a delay in capitalising on a changing international environment as the main reasons for failure. The persistent European deficit in $\mathrm{R} \& \mathrm{D}$ is, in his opinion, the result of a failure to promote the emergence and growth of innovative businesses in new sectors.

\subsection{Empirical model}

For the empirical model we follow a similar approach as in Section 4. Let $z_{i t}$ be an indicator of economic performance that is relevant for the LS. We first estimate a model

$$
z_{i t}=\alpha z_{i, t-1}+\beta x_{i t}+\gamma_{i}+\delta_{t}+\varepsilon_{i t}
$$

where the performance indicator is regressed on a vector of possible fundamental determinants $x$ (possibly also timed $t-1$ where reverse causality is a potential concern). Once we obtain a satisfactory parsimonious model for equation (4), we add the dummy variables capturing the LS:

$$
z_{i t}=\alpha z_{i, t-1}+\beta x_{i t}+\gamma_{i}+\delta_{t}+\phi L I S B O N_{i t}+\varepsilon_{i t}
$$

The coefficient $\phi$ captures the additional effect, coming on top of all other control variables, stemming from the fact that a given country is subject to a supra-national process, the LS. To simplify things, finding $\phi>0$ would imply that the LS has "worked" and that its success is visible in the data. Also in this case, as for the analysis of ex post fiscal behaviour, we emphasise the risk of selection bias, as it could well be that countries with structural weaknesses are precisely those which undertake a stronger reform effort, in the same way as patients who are more ill are more likely to take a certain medicine. In the case of the LS, this may be less of a concern since it applies indistinctly to the whole EU and the decision to join the EU (unlike, at least in part, the decision to join the euro area) largely reflects geographical 
and political determinants, not economic policy objectives. ${ }^{9}$ Furthermore, this is if anything a source of bias in the direction of finding $\phi>0$, rather than the other way round.

It should be recalled that the LS was an overarching strategy entailing not only an economic but also a social and environmental dimension. This was indeed identified as one of its weaknesses and may explain the poor performance in economic terms. We focus on the economic dimension and take three indicators as best overall measures of economic performance: (i) per capita income growth, (ii) labour productivity growth, and (iii) employment growth.

\subsection{Results}

Table 8 reports the results for per capita income growth. In estimating equation (4) and retaining the significant variables, we find that a few variables are robustly associated to per capita income growth. First, initial conditions matter: the lagged per capita income level has a negative sign, suggesting some catching up process. Second, trade openness is associated to stronger per capita income growth, as is (surprisingly from one angle but see below) a higher level of Employment Protection Legislation. Turning to the political and institutional variables, we find that Political Stability (note that a higher reading of this indicator implies less stability) and Proportional Representation are associated to higher per capita growth. The results indicate that countries with lower income per capita, higher trade openness, more employment protection, more political stability and with a proportional political system tend to experience higher per capita income growth. We also try a number of additional variables that turn out to be insignificant. We try the World Bank Rule of Law indicator, as in Rodrik et al. (2004), but we find this variable insignificant, though correctly signed. The insignificance is likely to be linked to two main differences between the analysis in this paper and Rodrik et al. (2004). First, we look at per capita income growth rather than levels. Second, our panel includes mostly rich countries, while the quality of institutions (such as the protection of property rights) are likely to explain the difference between poor and rich countries rather than the smaller differences among rich countries. Furthermore, economic size is also insignificant when included together with openness (though it is significant when included alone). Finally, we also try several variables capturing the country's political institutions, finding all of them insignificant (apart from those reported in Table 7). ${ }^{10}$

(Table 8 here)

\footnotetext{
${ }^{9}$ In addition, the point made earlier for the country fixed effects also applies to this part of the analysis.

${ }^{10}$ The OECD's Product Market Regulation is also insignificant, probably on account of the more limited data availability.
} 
The second column of Table 8 reports the same equation when adding the Lisbon dummy, which is insignificant. Column (3) then reports the LISBON_YEARS dummy, which caters for the possibility that the LS has a cumulative, investmentlike nature. Also this dummy variable is insignificant. The fourth to sixth columns present some robustness analysis, in particular (i) restricting the sample period to 1992-2009; (ii) taking out 2008 and 2009, the exceptional years of the global financial crisis; and (iii) excluding observations for very low income per capita. The results are practically unchanged, with the only exception of Proportional Representation that is not significant anymore in the 1992-2009 sample period. We conclude, therefore, that there is no evidence of an impact of the LS on per capita income growth for the EU countries.

Table 9 repeats the same exercise for labour productivity growth, another mainstay of the LS. Again, we find that lagged per capita income levels tend to have a negative impact on productivity growth, while again trade openness has a positive impact (though less robustly statistically significant than in the case of per capita income growth). We also find that a higher lagged wage share of income is significant, with a positive sign, indicating that a higher wage share of income fosters productivity growth. This may be due to the fact that a higher wage share of income makes capital more scarce and hence raises the marginal efficiency of capital, contributing to higher productivity growth. Once again, we try a number of additional variables which turn out to be insignificant in the estimated equation. The Lisbon dummies are here mostly significant but negatively signed, indicating that being part of the LS has reduced, rather than increased, labour productivity growth. One interpretation of this result, noted in some literature, is that the LS had to pursue two objectives that are difficult to reconcile simultaneously, that is, raising labour productivity and expanding employment. Efforts directed at the latter objective may have weakened the first objective. The results are robust to changing the sample period and when excluding the global financial crisis.

(Table 9 here)

Finally, Table 10 reports results for employment growth. In this case, we find labour force growth - a mainly demographic variable - strongly significant and positive, while the lagged employment share is negative, suggesting an error correction behaviour (countries with a higher employment share experiencing lower employment growth, and the other way round). There is also some evidence that the Vote Share of Government Parties (an indicator of the strength and stability of governments) exerts a positive impact. Contradicting the earlier result with per capita income growth as the independent variable, we find the OECD measure of Employment Protection Legislation to be insignificant, possibly because it is correlated to the employment share in levels, but not necessarily to the growth rate of employment. Not surprisingly at this stage, we find the LS dummies insignificant everywhere, except in column (3) where the LISBON_YEARS dummy is negatively signed. Overall, our results converge to the strong conclusion that the LS had, at best, no impact on the variables that it was set to positively contribute to.

(Table 10 here) 


\section{Conclusions}

This paper is an ex post analysis of whether two key elements of the EU and euro area economic governance, the Stability and Growth Pact and the Lisbon Strategy, achieved their goals a decade or more after they were established. We have looked at a wide range of annual data coming from 36 countries, over the sample period from 1980 to 2010; we have considered a large set of possible control variables, as well as variables which could interact with the success (or lack thereof) of the EU economic governance pillars. Overall, our results indicate that so far economic governance in the EU and the euro area has had limited or no success. For the Lisbon Strategy, our results are not likely to be found surprising. ${ }^{11}$ While the results on the effects of the Stability and Growth Pact may be found more surprising, they are consistent with the overall weakening of the Pact especially since 2003.

An optimistic reading of our results is that finding no effect of the SGP on fiscal outcomes is an indicator of success, since it implies that this set of rules has prevented the establishment of the monetary union in Europe to adversely affect fiscal behaviour, a risk that was emphasised widely in the run-up to the introduction of the single monetary policy. In this interpretation, our finding of no effect of the SGP on the average primary balance is largely a result of a two effects counteracting each other, that is, the positive effects of the SGP have counterbalanced the negative externalities of the common currency on countries' incentives towards fiscal prudence. Although there might be an element of truth in this interpretation, we do not find it entirely plausible. In any case our approach does not allow us to explicitly consider counterfactuals. We also consider that an appropriate set of fiscal rules in a monetary union should go beyond the no-change outcome and impose greater fiscal discipline than otherwise, on account of the possible negative spillovers that fiscal profligacy in individual countries may have on other members also through the single monetary policy, as well as the possible reduction in market discipline for individual Member States brought about by the common currency. Our results indicate that the SGP has not delivered according to this stricter benchmark. The main policy implication stemming from our analysis is that substantial progress, or a "quantum leap", is necessary in reforming EU and euro area economic governance going forward in order to ensure the continuing benefits of EMU for European citizens. This conclusion comes at a time when important reforms to economic governance are being contemplated in the EU following the proposals of the Commission on 29 September 2010.

In terms of questions for future research, we find that the interaction between supra-national rules such as the Stability and Growth Pact and the Lisbon Strategy and national fiscal and economic institutions is a promising field of investigation, which we have not pursued here owing to data limitations but which merits further attention.

\footnotetext{
${ }^{11}$ For example, Swedish prime minister Fredrik Reinfeldt wrote in June 2009 that "Even if progress has been made it must be said that the Lisbon Agenda, with only a year remaining before it is to be evaluated, has been a failure."
} 


\section{References}

[1] Afonso, A. and S. Hauptmeier (2009): "Fiscal behaviour in the European Union: rules, fiscal decentralization and government indebtedness", ECB Working Paper No. 1054.

[2] Alesina, A. and G. Tabellini (1990): "Voting on the budget deficit", American Economic Review, 80, 1, pp. 37-49.

[3] Alesina, A. and A. Drazen (1991): "Why are fiscal stabilisations delayed", American Economic Review, 81, pp. 1170-1180.

[4] Alesina, A. and R. Perotti (1999): "Budget deficits and budget institutions", in Poterba J. and J. von Hagen, Fiscal Institutions and Fiscal Performance, NBER, Chicago: University of Chicago Press.

[5] Alesina, A., and R. Wacziarg (1998): "Openness, country size, and government", Journal of Pulic Economics, 69, pp. 305-321.

[6] Alesina, A., Ardagna, S. and V. Galasso (2008): "The euro and structural reforms", NBER Working Paper No. 14479.

[7] Annett, A. (2006): "Enforcement and the Stability and Growth Pact: How fiscal policy did and did not change under Europe's fiscal framework", IMF Working Paper No. 06/116.

[8] Beck, T., Clarke, G., Groff, A., Keefer, P. and P. Walsh (2001): "New tools in comparative political economy: The Database of Political Institutions." 15:1, 165-176 (September), World Bank Economic Review.

[9] Bernoth, K., Hughes Hallet, A. and J. Lewis (2009): "Did fiscal policy makers know what they were doing? Reassessing fiscal policy with real time data", CEPR Discussion Paper No. 6758.

[10] Beetsma, R., Giuliodori, M. and P. Wierts (2009): "Budgeting versus implementing fiscal policy in the EU", Economic Policy, forthcoming.

[11] Boeri, T., Castanheira, M., Faini, R. and V. Galasso (2006): Structural reforms Without Prejudices, Oxford University Press.

[12] Buiter, Willem H. (2005): "The "Sense and Nonsense of Maastricht" Revisited: What Have We Learnt About Stabilization in EMU?", Discussion Paper Series - No. 5405, Centre for Economic Policy Research.

[13] Bulut, L. (2009): "Market Disciplining of the Developing Countries' Sovereign Governments", available at SSRN: http://ssrn.com/abstract=1323440. 
[14] Buti, M., Eijffinger, S. and D. Franco (2003): "Revisiting EMU's Stability Pact: A pragmatic way forward", Oxford Review of Economic Policy, Volume 19, Number 1 .

[15] Buti, M. and P. Noord (2004): "Fiscal Discretion and Elections in the Early Years of EMU", Journal of Common Market Studies, 42, 4, pp. 737-756.

[16] Buti, M. and L. Pench (2004): "Why do Large Countries Flout the Stability Pact And What Can be Done About it?", Journal of Common Market Studies 42, 5, pp. 1025-32.

[17] Buti, M., Roger, W., and A. A. Turrini (2009): "Is Lisbon far from Maastricht? Trade-offs and complementarities between fiscal discipline and structural reforms", CESifo Economic Studies, 55, 1, pp. 165-196.

[18] Cimadomo J. (2005): "Has the Stability and Growth Pact Made Fiscal Policy more Pro-Cyclical?", La Lettre du CEPII, CEPII research center, issue 247.

[19] Cimadomo, J. (2008): "Fiscal policies in real time", ECB Working Paper No. 919.

[20] Collignon, Stefan (2009): "The Lisbon Strategy, macroeconomic stability and the dilemma of governance with governments; or why Europe is not becoming the world's most dynamic economy", International Journal of Public Policy, vol. 3, nos. 1/2, pp. 72-99.

[21] de Haan, J. and J.-E. Sturm (2000): "Do financial markets and the Maastricht Treaty discipline governments? New evidence", Applied Financial Economics, 10, 2, pp. 221-26.

[22] Debrun, X. and M. S. Kumar (2007): "The discipline-enhancing role of fiscal institutions: theory and empirical evidence", IMF Working Paper No. 07/171.

[23] Drazen, A. (2000): "The political business cycle after 25 years", in B. Bernanke and K. rogoff eds., NBER Macroeconomics Annual 2000, Cambridge: MIT Press.

[24] Duval, R. and J. Elmeskov (2006): "The effects of EMU on structural reforms in labour and product markets", ECB Working Paper No. 596.

[25] European Central Bank (2005): The reform of the Stability and Growth Pact, Monthly Bulletin, Frankfurt.

[26] - (2008), The Euro at ten - lessons and challenges, Fifth ECB central banking conference, 13-14 November.

[27] European Commission (2005): Working together for growth and jobs - A new start for the Lisbon Strategy, Brussels. 
[28] European Commission (2008): EMU@10: Successes and challenges after ten years of Economic and Monetary Union, Luxembourg, Office for Official Publications of the European Communities.

[29] Fatás, Antonio and Ilian Mihov (2003): "On constraining fiscal policy discretion in EMU", Oxford Review of Economic Policy, Volume 19, Number 1.

[30] Filipek, A. K. and T. Schreiber (2010): "The Stability and Growth Pact: Past Performance and Future Reforms", College of William and Mary Department of Economics - Working Paper \#97.

[31] Gali, J. and R. Perotti (2003): "Fiscal policy and monetary integration in Europe", Economic Policy, 18, pp. 533-572.

[32] Golinelli, R. and S. Momigliano (2009): "The cyclical reaction of fiscal policies in the euro area: the role of modelling choices and data vintages", Fiscal Studies, 30, 1, pp. 39-72.

[33] Hallerberg, M. (2004): Domestic Budgets in a United Europe: Fiscal Governance from the end of Bretton Woods to EMU, Cornell University Press, Ithaca and London.

[34] Hodson, D. (2009): "National Fiscal Institutions and the Stability and Growth Pact: Are 'Delegation' States at a Disadvantage?", in Policy Instruments for Sound Fiscal Policies: Fiscal Rules and Institutions, Ayuso-i-Casals J., Deroose S., Flores E. and Moulin L. (eds), Palgrave Macmillan.

[35] Imbens, G. W. and J. M. Wooldridge (2009): "Recent developments in the econometrics of program evaluation", Journal of Economic Literature, 47, 1, pp. $5-86$.

[36] International Monetary Fund (2004): "Fostering Structural Reforms in Industrial Countries", World Economic Outlook.

[37] International Monetary Fund (2006): "Euro Area Policies", IMF Country Report No. 06/287, June 30.

[38] International Monetary Fund (2006): "Euro Area Policies", IMF Country Report No. 10/221, July 1.

[39] Ioannou, D., Ferdinandusse, M., Lo Duca, M., Coussens, W., Cipollone, P., Rosolia, A. and H. E. Stahl (2008): "Benchmarking the Lisbon Strategy", ECB Occasional Paper No. 85.

[40] Jonung, L. and M. Larch (2006): "Improving fiscal policy in the EU: the case for independent forecasts," Economic Policy, 21, 47, pp. 491-534. 
[41] Judson, R. A. and A. L. Owen (1999): "Estimating dynamic panel models: a guide for macroeconomists", Economics Letters, 65, pp. 9-15.

[42] Kaufmann, D., Kraay and M. Mastruzzi (2008): "Governance Matters VII: Governance Indicators for 1996-2007", World Bank Policy Research Working Paper No. 4654 .

[43] Koczor, Marcin (2009): "Lisbon Strategy implementation in 2008: An Analysis", The Polish Institute of International Affairs, Warsaw, 6 March.

[44] Kok W. et al. (2004): "Facing the Challenge: The Lisbon Strategy for Growth and Employment", Report from the High Level Group chaired by Wim Kok.

[45] Kopits G. and S. Symansky (1998): "Fiscal policy rules", IMF Occasional Paper Series No. 162.

[46] Lambertini, L. (2000), "On the redistributive property of budget deficits", in J. Von Hagen and R. Strauch eds, Institutions, Politics and Fiscal Policy, Kluwer Academic Publisher: Boston, Dordrecht, London

[47] Lane, T. D. (1993): "Market discipline", IMF Staff Papers, 40, 1.

[48] Morris, R., Ongena, H. and L. Schuknecht (2006): "The reform and implementation of the Stability and Growth Pact", ECB Occasional Paper No. 47.

[49] Nickell, S. J. (1981): "Biases in Dynamic Models with Fixed Effects", 49, 6, pp. $1417-26$.

[50] OECD (2005): "Economic Survey of the Euro Area 2005: Putting the fiscal house in order", Paris, 12 July.

[51] Padoan, P. C. (2009): "Revising the Lisbon Strategy through the OECD Innovation Strategy", Incom Workshop on Innovation and Growth Policy in the EU, Prague, 22-23 January.

[52] Persson, T. and L. Svensson (1990): "Why a Stubborn Conservative Would Run a Deficit: Policy with Time Inconsistency Preferences", Quarterly Journal of Economics, 104, pp. 325-45.

[53] Rodrik, D., Subramanian, A. and F. Trebbi (2004): "Institutions rule: the primacy of institutions over geography and integration in economic development", Journal of Economic Growth, 9, pp. 131-165.

[54] Roubini, N. and J. Sachs (1989): "Government Spending and Budget Deficits in the Industrial Economies," NBER Working Papers No. 2919.

[55] Ruta, M. (2009): "Why Lisbon Fails", CESifo Economic Studies, vol. 55, 1/2009. 
[56] Schelkle, W. (2005): "The Political Economy of Fiscal Policy Co-ordination in EMU: From Disciplinarian Device to Insurance Arrangement", Journal of Common Market Studies, 43, 2, pp. 371-91.

[57] Schout, A. and A. Jordan (2008): "The European Union's governance ambitions and its administrative capacities", Journal of European Public Policy, vol. 15, no. 7, pp. 957-974.

[58] Schuknecht, L. (2005): "EU fiscal rules: issues and lessons from political economy", International Economics and Economic Policy, 2, pp. 65-89.

[59] Tompson, W. (2009): Political economy of reform: Lessons from pensions, product markets and labour markets in ten OECD countries, Paris: OECD.

[60] von Hagen, J. (2003): "Fiscal Discipline and Growth in Euroland: Experiences with the Stability and Growth Pact", ZEI Working Paper B 06.

[61] Wyplosz, C. (2010): "The failure of the Lisbon strategy", http://www.voxeu.org/index.php?q=node/4478. 
TABLE 1. Synoptic table: Empirical literature on the effects of the SGP

\begin{tabular}{|c|c|c|c|c|}
\hline Author(s) & $\begin{array}{l}\text { Estimation } \\
\text { approach / } \\
\text { method }\end{array}$ & Sample & Period & Main results \\
\hline $\begin{array}{l}\text { Afonso and } \\
\text { Hauptmeier (2010) }\end{array}$ & $\begin{array}{l}\text { Panel/ } \\
\text { LSDVc }\end{array}$ & EU-27 & $\begin{array}{l}1990- \\
2005\end{array}$ & $\begin{array}{l}\text { - Positive impact of the SGP on the } \\
\text { primary balance, but not on primary } \\
\text { expenditure. } \\
\text { - Negative impact of the electoral } \\
\text { cycle. }\end{array}$ \\
\hline Cimadomo (2005) & $\begin{array}{l}\text { Panel/ } \\
\text { Estimation of } \\
\text { linear and non- } \\
\text { linear } \\
\text { relationships }\end{array}$ & $\begin{array}{l}\text { Euro } \\
\text { area } \\
\text { except } \\
\text { GRC } \\
\text { and } \\
\text { LUX }\end{array}$ & $\begin{array}{l}1981- \\
2005\end{array}$ & $\begin{array}{l}\text { - No significant evidence of a pro- } \\
\text { cyclical bias in downturns induced } \\
\text { by the SGP. } \\
\text { Tighter policies when public } \\
\text { indebtedness grows. } \\
\text { - The policy is a-cyclical in case of } \\
\text { positive output gap. } \\
\text { - Fiscal decentralisation contributes } \\
\text { to an increase in the total primary } \\
\text { spending-to-GDP ratio. }\end{array}$ \\
\hline $\begin{array}{lr}\text { Forni } & \text { and } \\
\text { Momigliano (2005) }\end{array}$ & $\begin{array}{l}\text { Panel / } \\
\text { OLS, FE-IV, } \\
\text { GMM }\end{array}$ & $\begin{array}{l}\text { Euro } \\
\text { area, } \\
\text { except } \\
\text { LUX } \\
\text { and } \\
\text { IRL }\end{array}$ & $\begin{array}{l}1993- \\
2003\end{array}$ & $\begin{array}{l}\text { The differences between real-time } \\
\text { and ex post data are substantial and } \\
\text { tend to be systematic across time. } \\
\text { No major differences between } \\
\text { OECD and euro area countries } \\
\text { when it comes to fiscal reaction in } \\
\text { bad times. }\end{array}$ \\
\hline $\begin{array}{l}\text { Gali and Perotti } \\
(2003)\end{array}$ & $\begin{array}{l}\text { Panel / } \\
\text { FE IV }\end{array}$ & EA-11 & $\begin{array}{l}1980- \\
2002\end{array}$ & $\begin{array}{l}\text { Discretionary fiscal policy in EMU } \\
\text { countries has become more } \\
\text { countercyclical over time, as } \\
\text { observed in other countries, even if } \\
\text { OECD countries are more } \\
\text { countercyclical. } \\
\text { Decline in public investment } \\
\text { experienced over the last decade by } \\
\text { EMU countries is also part of a } \\
\text { global trend and is smaller than in } \\
\text { OECD countries. }\end{array}$ \\
\hline Annett (2006) & $\begin{array}{l}\text { Panel / } \\
\text { pooled OLS, FE, } \\
\text { 2SLS }\end{array}$ & EA-11 & $\begin{array}{l}1980- \\
2004\end{array}$ & $\begin{array}{l}\text { - Asymmetric success in the } \\
\text { implementation of the SGP is } \\
\text { linked to the size, volatility as well } \\
\text { as commitment policy of each euro } \\
\text { area country. }\end{array}$ \\
\hline $\begin{array}{l}\text { Bernoth et al. } \\
(2010)\end{array}$ & $\begin{array}{l}\text { Panel / } \\
\text { FD GMM }\end{array}$ & EU-14 & $\begin{array}{l}1995- \\
2006\end{array}$ & $\begin{array}{l}\text { The pro-cyclicality of fiscal policies } \\
\text { only arises in the ex post data. } \\
\text { Real time data suggests that } \\
\text { policymakers have tried to run } \\
\text { counter-cyclical discretionary } \\
\text { policy, but find it hard to do. }\end{array}$ \\
\hline
\end{tabular}

Note: LSDVc is the least square dummy variable estimator corrected for a dynamic panel data setting; FE is the fixed-effect estimator; FE-IV is the fixed effect estimator using instrumenta variables to deal with the endogeneity problem; 2SLS is the two-stage least square estimator ${ }^{1}$

GMM is the generalised method of moments estimator; FD GMM is the first-difference GMM (Blundell-Bond) estimator. 
TABLE 2. List of countries

\begin{tabular}{cc}
$E U$ & Non-EU \\
\hline Austria & Australia \\
Belgium & Canada \\
Bulgaria & Iceland \\
Cyprus & Japan \\
Czech Republic & Republic of Korea \\
Denmark & Mexico \\
Estonia & New Zealand \\
Finland & Norway \\
France & Switzerland \\
Germany & Turkey \\
Greece & USA \\
Hungary & \\
Ireland & \\
Italy & \\
Latvia & \\
Lithuania & \\
Luxembourg & \\
Netherlands & \\
Poland & \\
Portugal & \\
Romania & \\
Slovak Rep. & \\
Slovenia & \\
Spain & \\
UK & \\
\hline
\end{tabular}




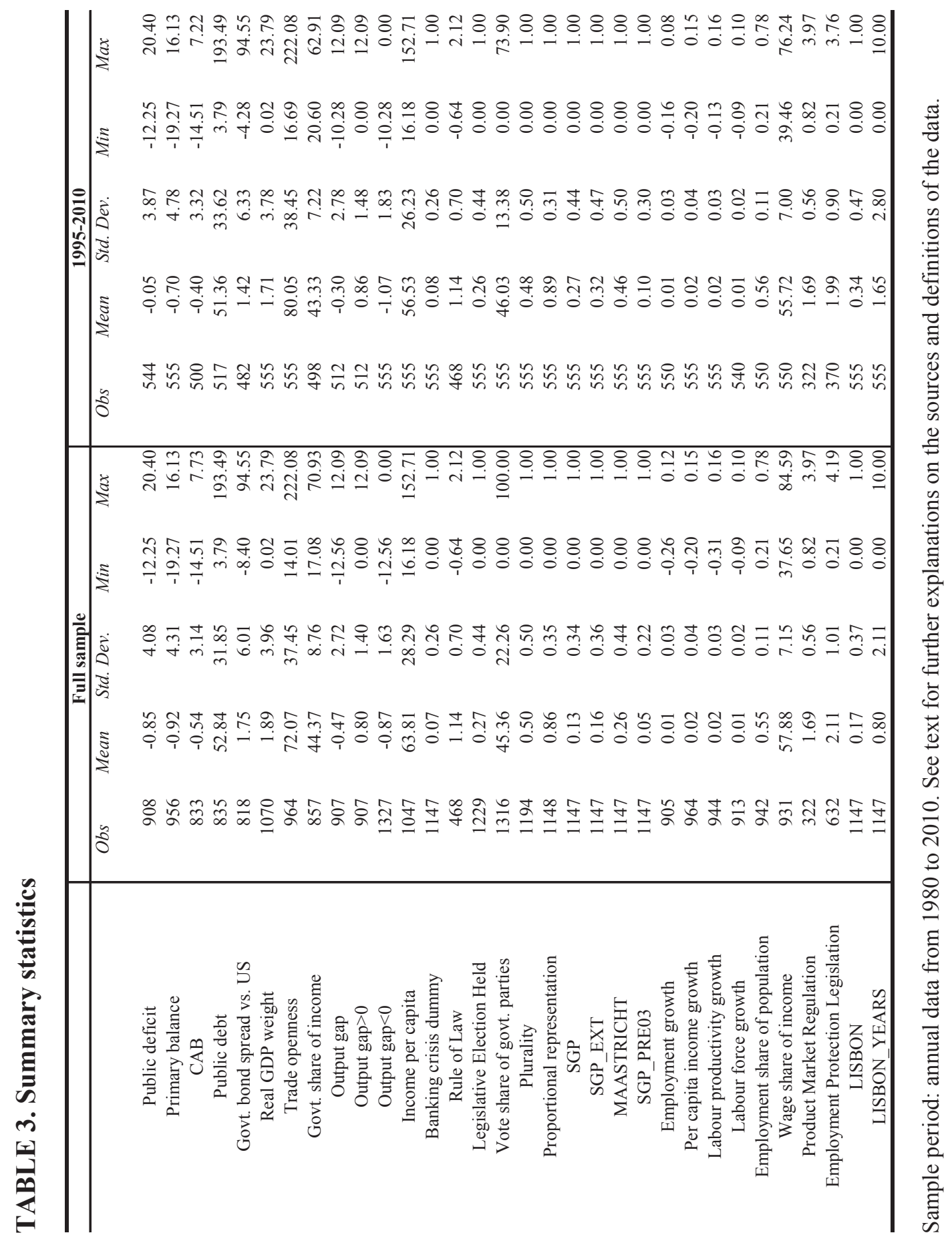


TABLE 4. Unconditional moments of the primary balance and per capita growth

\begin{tabular}{|c|c|c|c|}
\hline & Obs. & Mean & Std. dev. \\
\hline & \multicolumn{3}{|c|}{ Primary balance } \\
\hline Full sample & 956 & -0.92 & 4.31 \\
\hline No SGP & 806 & -1.17 & 4.42 \\
\hline SGP & 150 & 0.39 & 3.39 \\
\hline No SGP_PRE & 778 & -1.27 & 4.44 \\
\hline SGP_PRE & 178 & 0.58 & 3.3 \\
\hline No MAASTRICHT & 662 & -1.41 & 4.56 \\
\hline MAASTRICT & 294 & 0.18 & 3.46 \\
\hline No SGP_PRE03 & 899 & -1.12 & 4.33 \\
\hline \multirow[t]{2}{*}{ SGP_PRE03 } & 57 & 2.16 & 2.36 \\
\hline & \multicolumn{3}{|c|}{ Per capita growth } \\
\hline Full sample & 964 & 2.2 & 3.7 \\
\hline No Lisbon & 774 & 2.4 & 3.5 \\
\hline Lisbon & 190 & 1.2 & 4.4 \\
\hline
\end{tabular}

Note: See text for the definition of the dummy variables. All data are in percentage points per year. The full sample goes from 1980 to 2010 (annual data). 


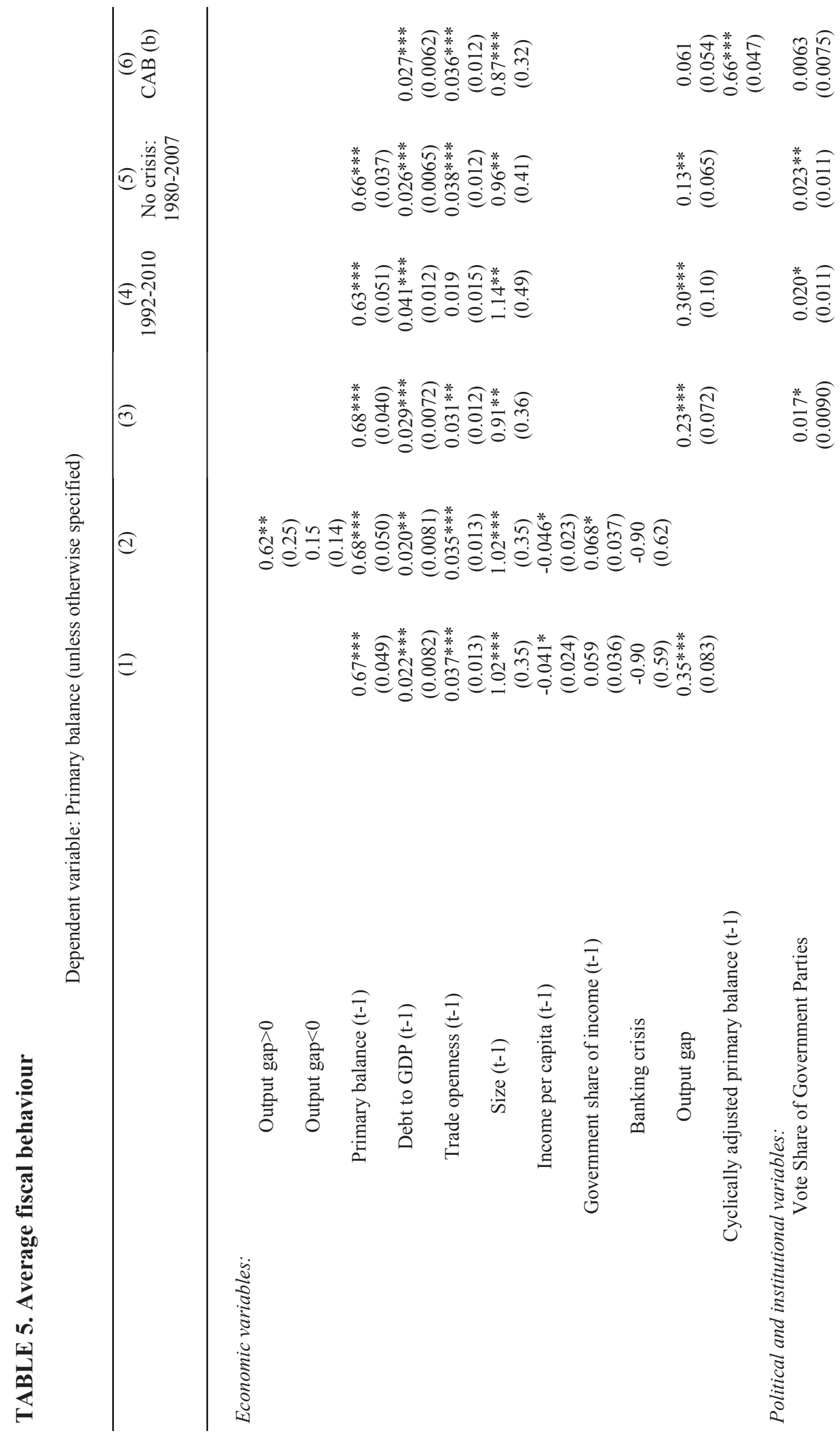




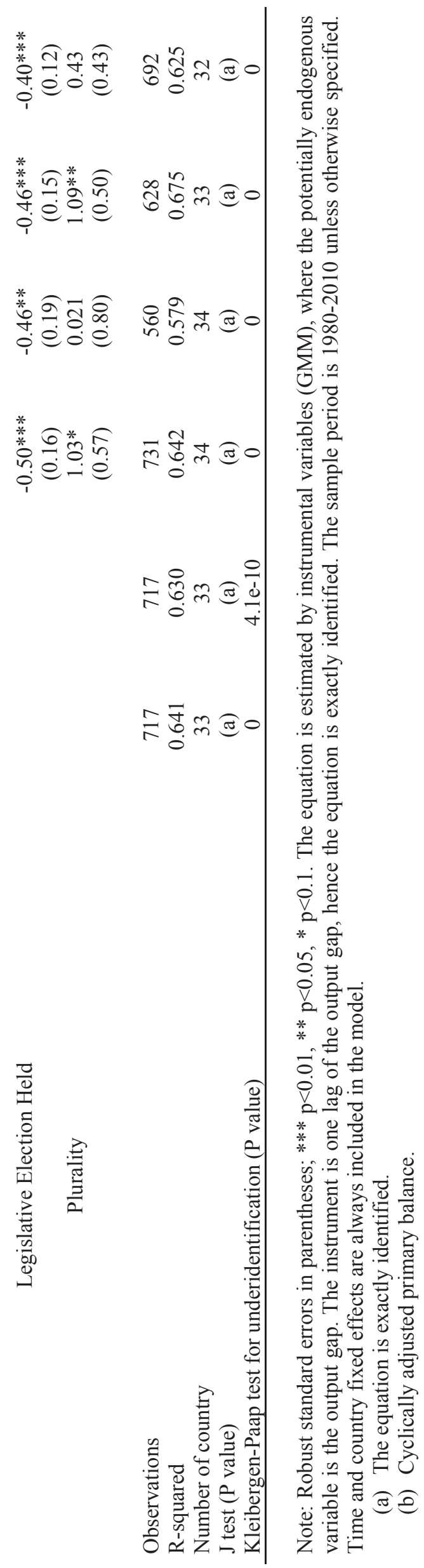




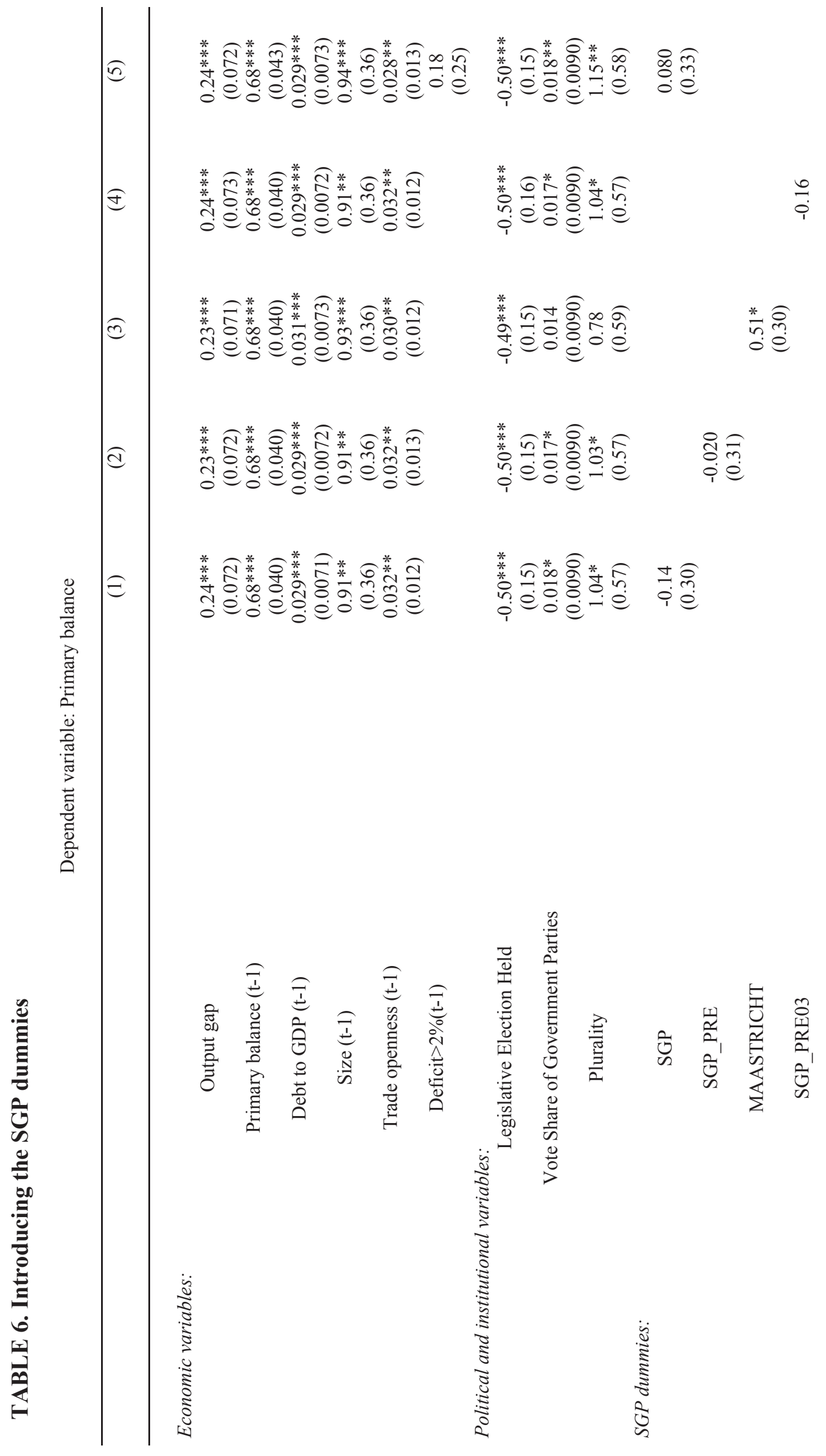




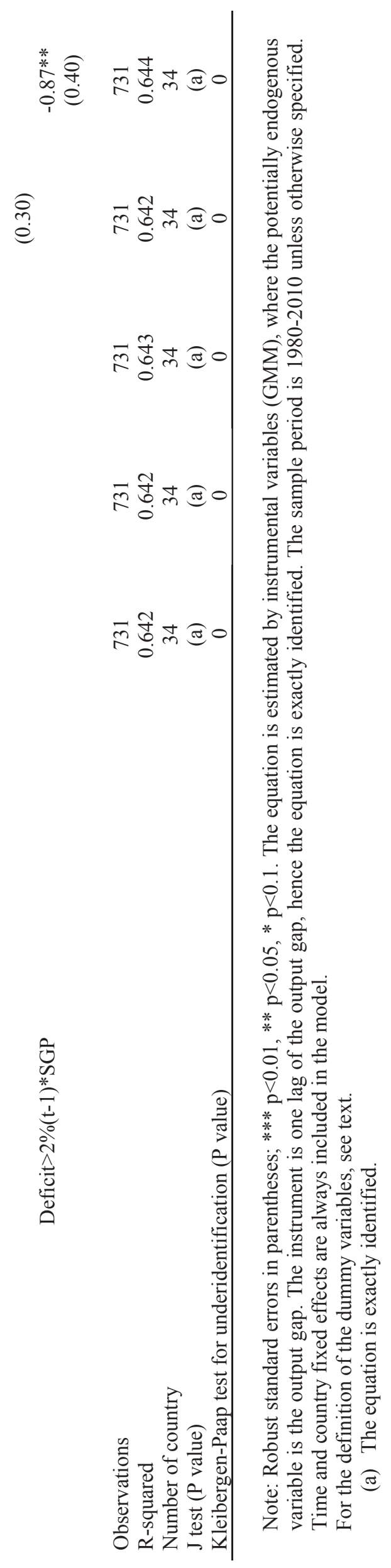




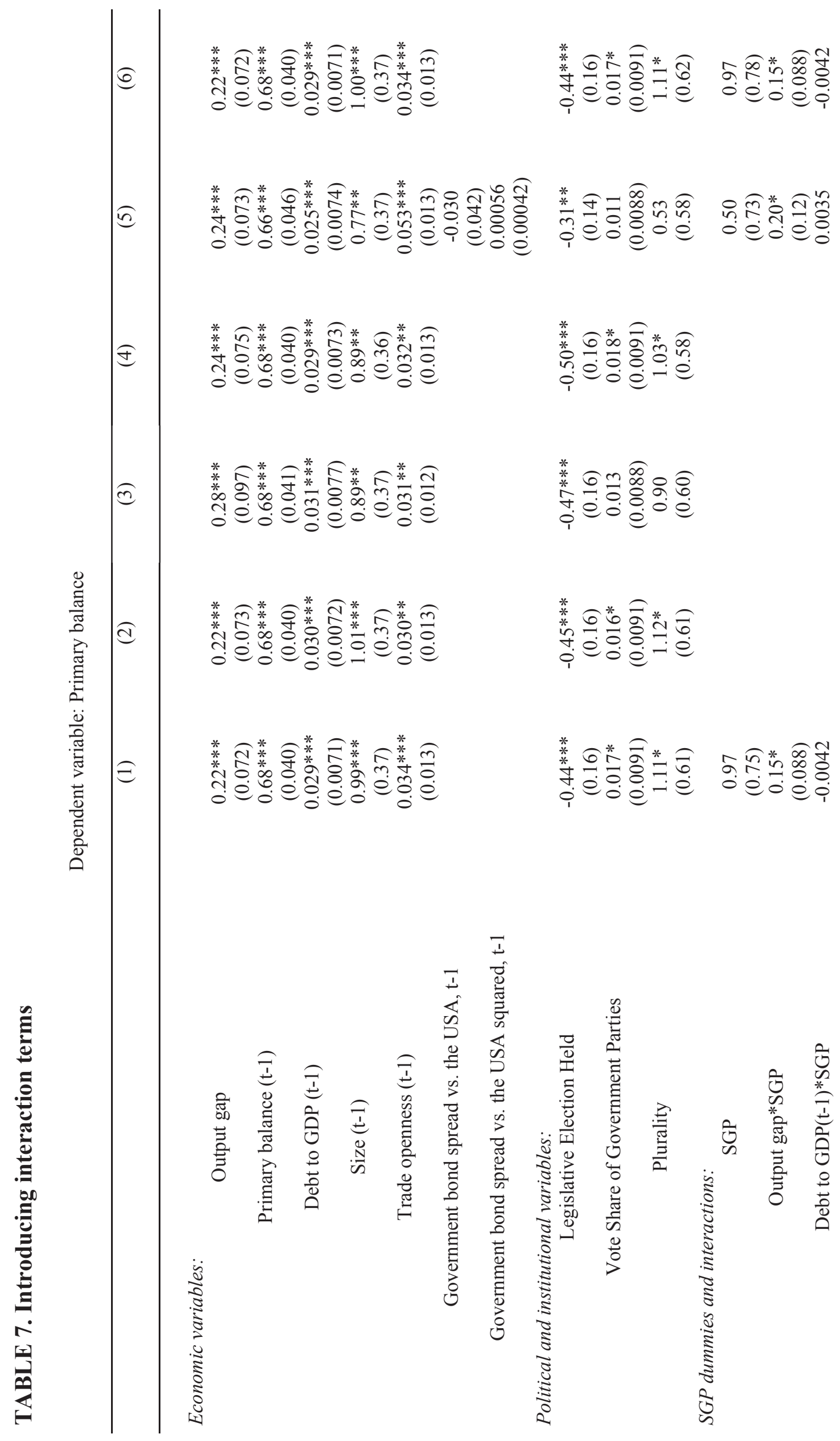




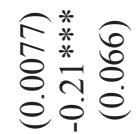

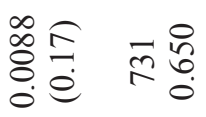

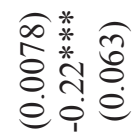

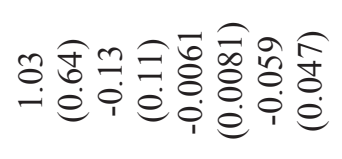$$
\text { ถู่ }
$$

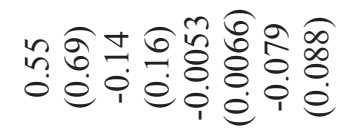

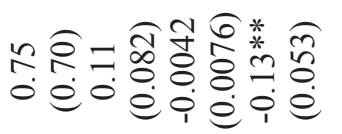

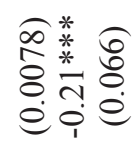

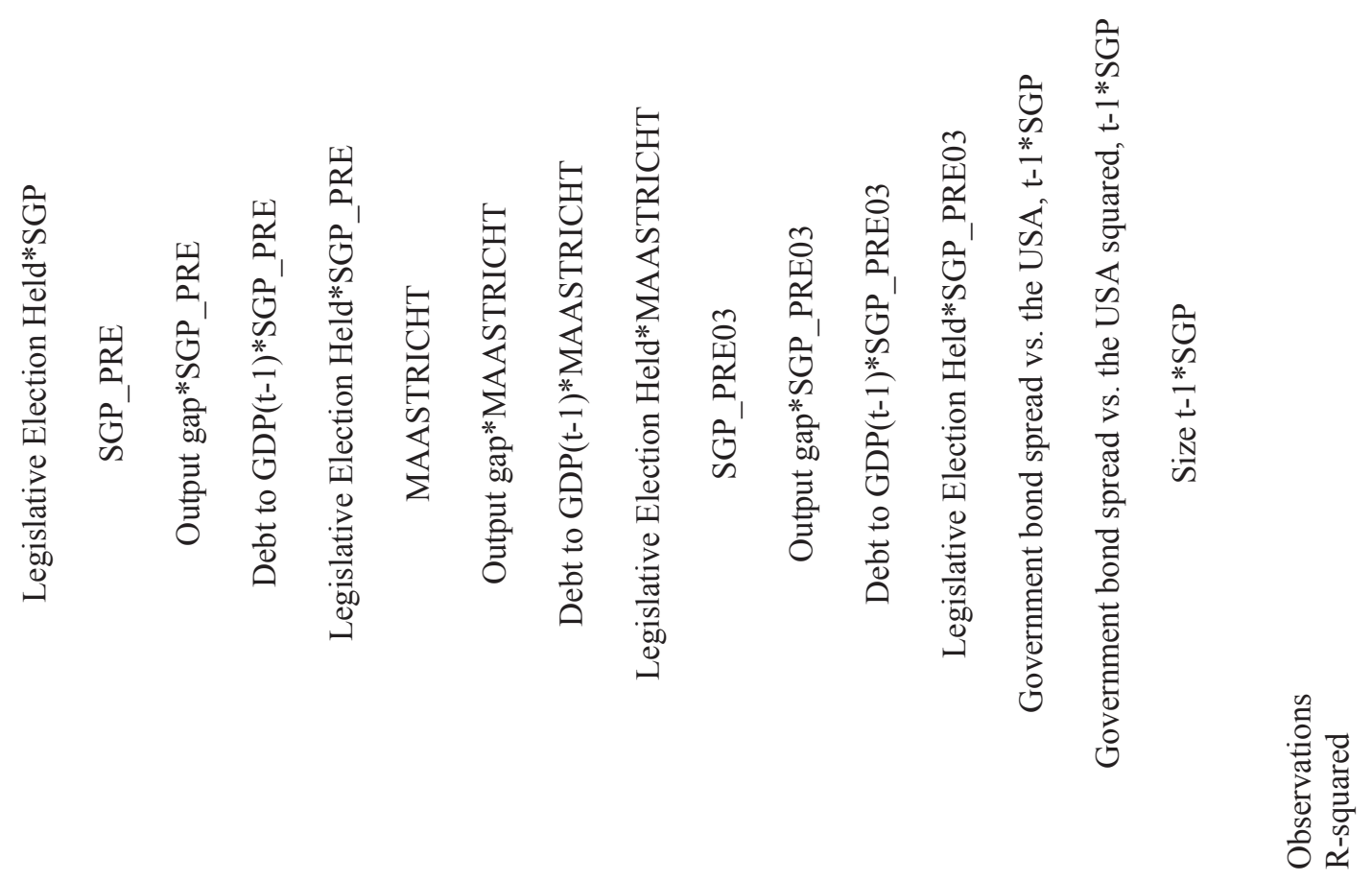




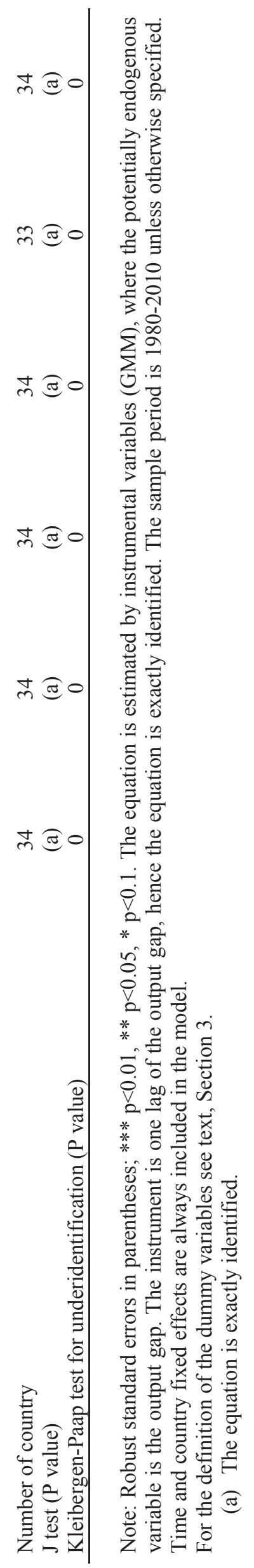




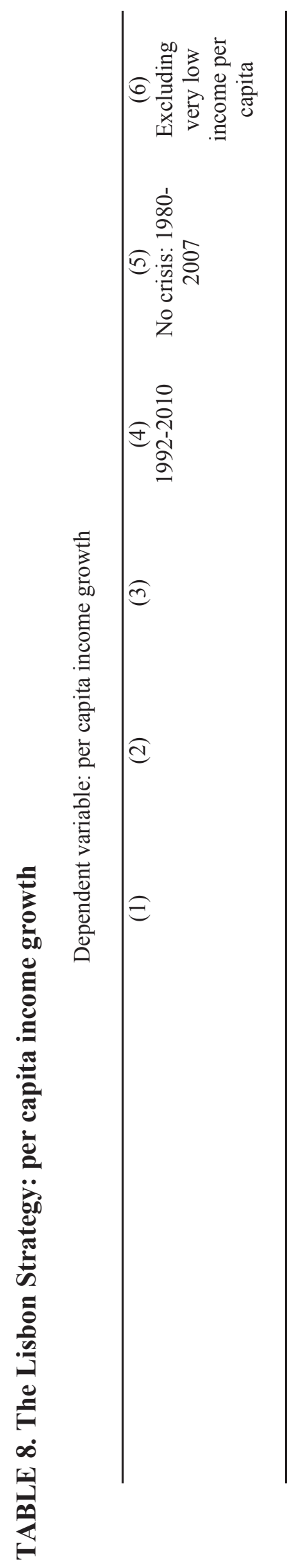

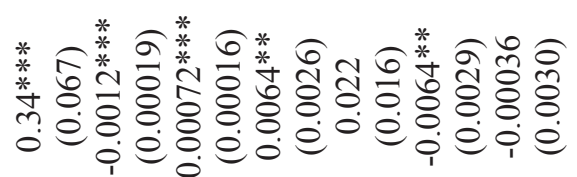

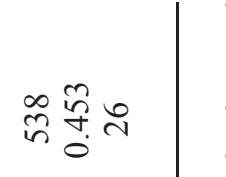

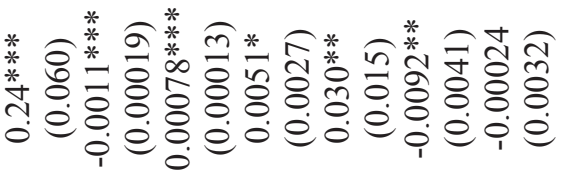

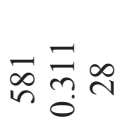

*

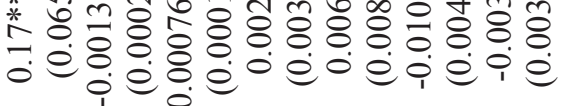

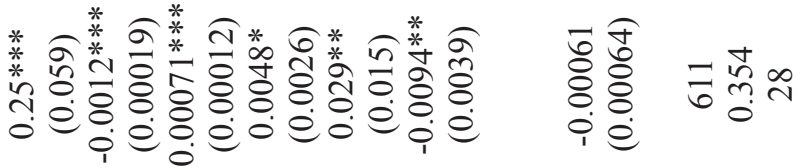

莺

웅

1
0
0
0
0
0
0
0

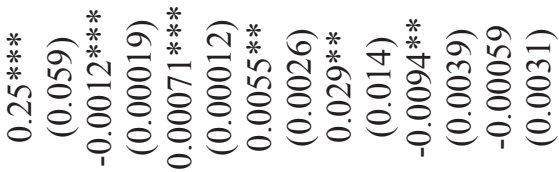

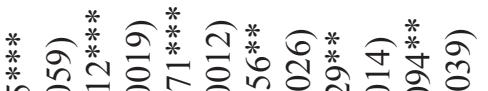
ڤ̂. च ప $\tilde{n}_{0}^{\infty}$

$\forall$

*

ก.

a

*i

$\stackrel{\square}{\ddagger}$

*

该:

造

氖

है

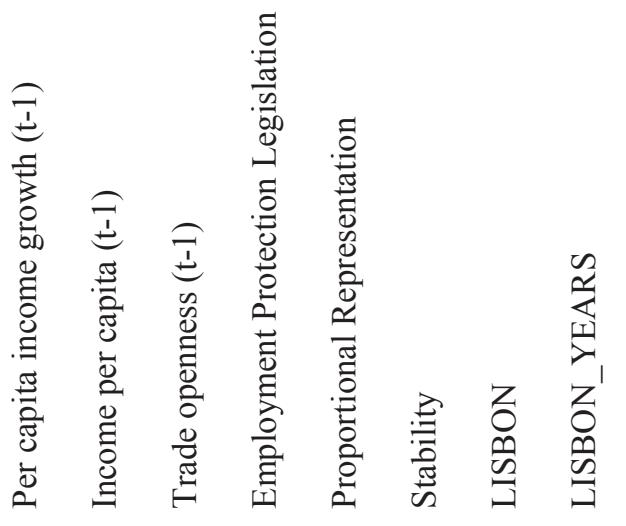

흉

:

플

预

क

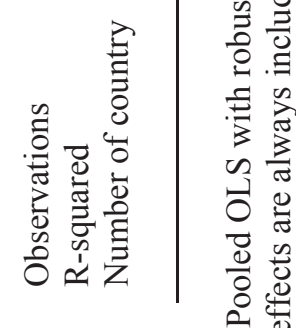

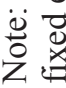




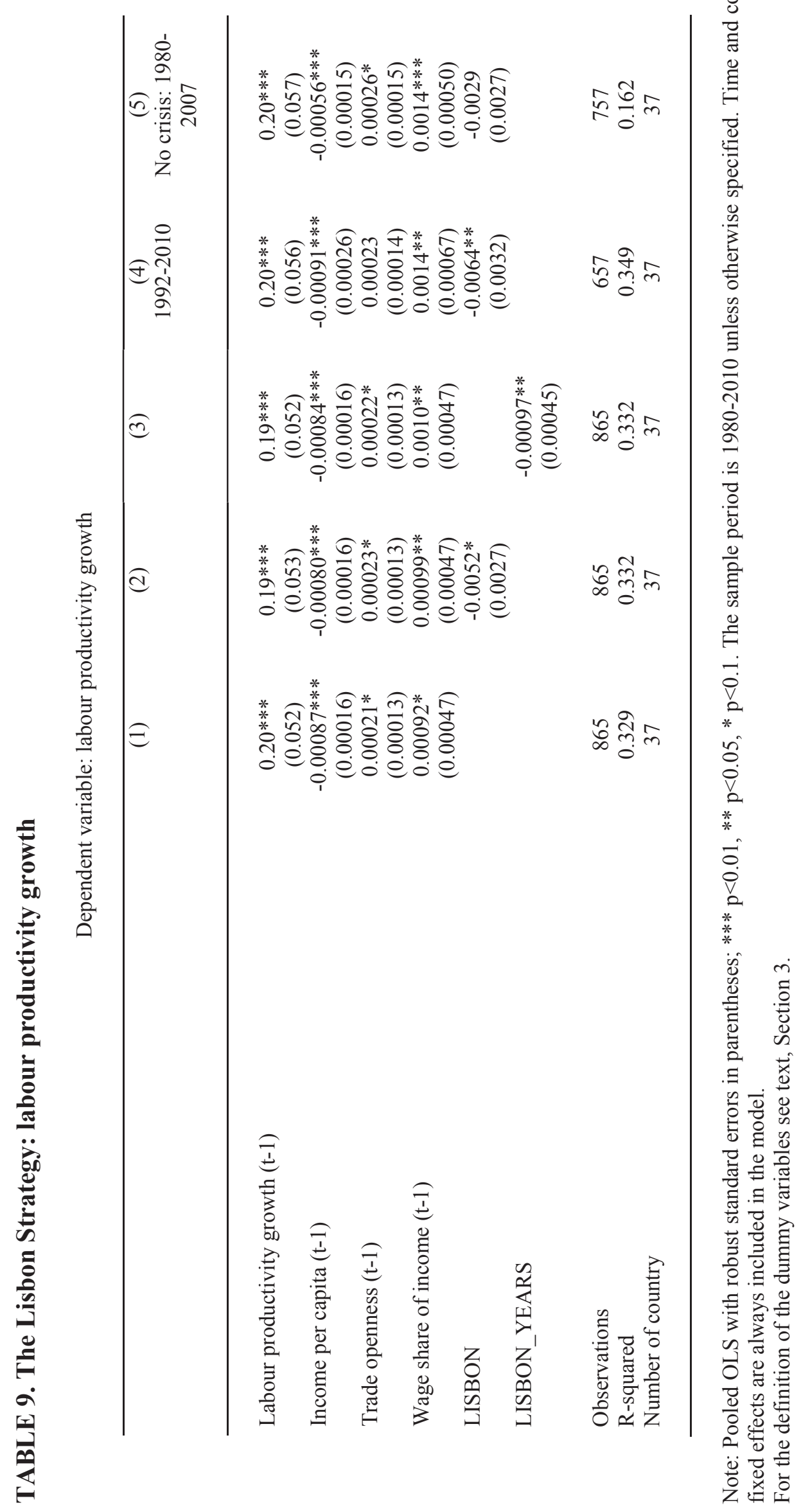




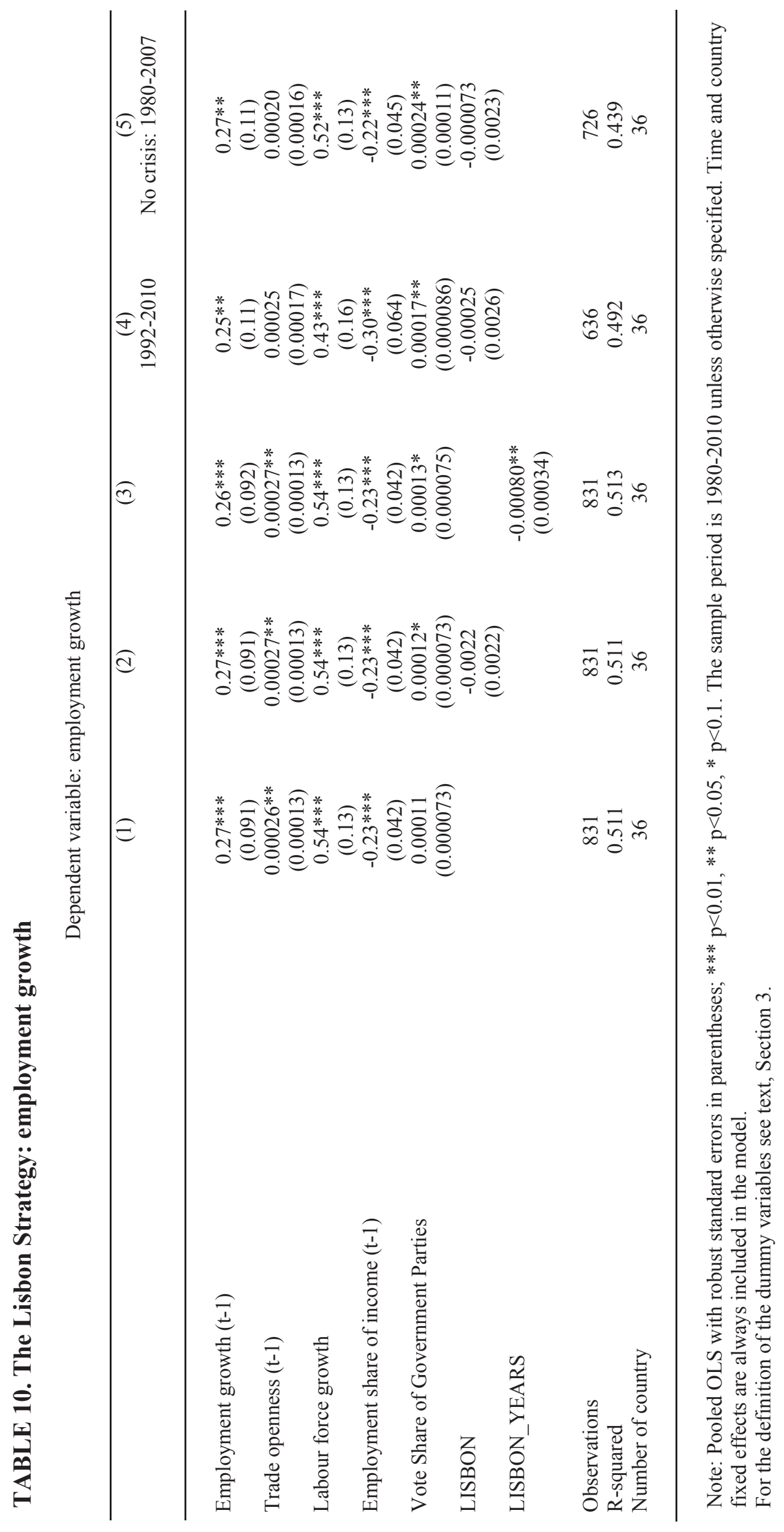


